\title{
Local Government Administration and Rural Development in Enugu State, Nigeria (2007-2015)
}

\author{
Ogbette, Afamefuna Samuel (corresponding author) \\ Department of Public Administration and Local Government \\ University of Nigeria, Nsukka \\ E-mail: ogbetteafamefuna@ymail.com \\ Idam, Macben Otu \\ Department of Public Administration and Local Government \\ University of Nigeria, Nsukka \\ E-mail: macben.idam@unn.edu.ng \\ Kareem, Akeem Olumide \\ Department of Public Administration and Local Government \\ University of Nigeria, Nsukka \\ E-mail: olumideak14@gmail.com
}

Received: Aug. 7, 2018 Accepted: Aug. 30, 2018 Online published: Sep. 5, 2018

doi:10.5296/jpag.v8i3.13608 URL: https://doi.org/10.5296/jpag.v8i3.13608

\begin{abstract}
This study examined Local Government Administration and Rural Development in Enugu State, Nigeria under Sullivan I. Chime's administration, 2007-2015. The source of information for this study is secondary source. Three research questions and three objectives guided this study. The general objective of the study is the relationship between the local government administration and rural development in Enugu State, Nigeria. The specific objectives were: to assess the role of the local government administration in rural development in Enugu State, to investigate whether job creation and provision of infrastructures by the government led to decline in rural-urban migration and to find out the relationship between governments budgetary allocation and rural development in Enugu State.
\end{abstract}


Giving the descriptive and argumentative nature of the paper, qualitative method of data gathering and analysis were adopted in the conduct of the research. The method of data presentation and analysis adopted for this study is the content analytical method. Some findings of the study include that Enugu State worked aggressively and assiduously to achieve developmental projects in different communities towards improving the standard of living. The state also came up with different initiatives/programmes like Visit Every Community (VEC), Free Maternal Child Healthcare (FMCH), Free Basic Education Policy and Songhai Initiative for the development of the state, and it was discovered that government budgetary allocations actually affected the overall development of the rural communities over limited resources. As a result of the above findings, the study made some recommendations which include among others; the roles played by the local governments can be said to be very successful. Though, there is need for the government to increase their function capacity of these projects and programmes to be able to cover every area of the state. Local government needs to diversify their internal revenue sources by engaging in some business ventures like filling stations, transportation, and so on, to be able to compliment the poor budgetary allocation given to them by the federal and state government.

Keywords: government, administration, rural, development, Enugu, Nigeria

\section{Introduction}

The idea of local government administration in Nigeria has attracted serious attention both nationally and internationally since the local government reform of 1976. Agagu, 1997, viewed local government as a level of government which is supposed to have its greatest impact on the people at the rural areas. It is a tier of government which is closest to the citizenry and it is saddled with responsibility of guaranteeing the political, social and economic development of its area and its people (Enero, Oladoyin and Elumilade, 2004).

As a result of this development, there has been growing recognition of the importance of rural development as an instrument in the overall development of the contemporary developing world. This is because of the glaring gap between the rural and urban areas in terms of infrastructural, resources distribution, human resources development and employment, which has made rural development imperative (Ogbazi, 1982 in Zakari ya'u, 2014). This imbalance has subjected the rural areas to more disadvantaged economic position. It has induced rural urban migration, thereby, increasing unemployment situation in the urban areas, while, simultaneously depriving the rural areas of their agricultural workforce (Zakari ya'u, 2014).

The idea of local government is to bring governance closer to people in the grassroots for participation in governance, service delivery to enhance socio-economic development and good governance (Ogunna, 1996 in Okoli, et al, 2015). But unfortunately today, transparency and accountability in Nigerian local government is rhetoric, most local government officials display provocative wealth gotten through criminal institutionalized stealing and corrupt practices (Onah, 2010 in Okoli, et al, 2015).

The failure of local government in the area of service delivery over the years has made the citizens to lose faith and trust in local government administration as an institution in Nigeria. 
From historical perspective, modern local government administration in Nigeria can be traced to the British system of local government. But it should be stated however, that local administration did not start with the advent of British Administration in Nigeria, because some forms of system of local government administration pre-dated the British rule. Local government administration is one of man's oldest institutions. The earliest form of local governments' administration existed in the form of clan and village meetings. In fact, democracy itself originated and developed along the lines of local governance initiative in the ancient Greek City States. It should be noted however, that in other parts of the world, local governance was developed along the people's culture and expectations, and the system was tied to the norms and practices of the people (Aghayere, 1997).

According to Gboyega, four points of historical reference can be identified in the development of local government administration in Nigeria. They are: (1) Colonial rule; (2) Local government reforms in the East (1951) and West (1952) respectively; (3) The military coup of 1966; and (4) The 1976 Local Government Reform (Gboyega as cited by Aghayere 1997 in Oviasuyi et al, 2010).

Local government administration in Nigeria has undergone many changes of which the 1976 Reforms and the Constitutions of 1979 and 1999 can be said to be most prominent. Before 1976, local government administration in Nigeria had passed through many changing environments and this has in no small measure influenced its development. Again, the 1976 Local Government Reforms brought watershed in local government system; the reform brings unified structure and makes local government bedrock for development in the rural area (Agagu, 2004, Ajayi, 2000).

The reform was a major departure from the previous practice of local government administration in Nigeria. The philosophical basis of the reform lies in the conviction that a strong local authority with clearly defined functional responsibilities in a power-sharing relationship with the states is an institutional safeguard against tyranny. Following the 1976 reforms, local government became recognized as a tier of government entitled to a share of national revenue consequent on its constitutionally allocated functions (Imuetinyan 2002 in Oviasuyi et al, 2010)

The provisions of the 1976 reform document were incorporated into the 1979 Constitution of the Federal Republic of Nigeria. Section 7(1) of the constitution provides that "the government of every state shall ensure their existence under a law which provides for the establishment, structure, composition, finance and functions of such councils" Constitution of the Federal Republic of Nigeria (1979).

The power of the state government over local authorities has been wrongly applied to undermine elected and participatory governance and responsibility at the grassroots, and this has made operation of the constitution questionable. The situation of local government administration under the 1999 Constitution is also very confusing and complex. Although, the 1999 Constitution also guarantees the existence of a democratically elected local government system, it however, like the 1979 Constitution, gives the states the responsibility to handle issues of organization and structure (Oviasuyi et al, 2010). 
As a result of this development, most of the rural areas in Nigeria are in a pathetic state of development, even, some of the urban local government areas are also deficient in development. Some of these infrastructures where available, are left uncared for. The implication of this is that local governments in Nigeria have been consistent over the years in their failure to enhance their capacity to engage and mobilize human resources towards their needs. Local roads are left unrepaired, rural electricity are in state of dilemma, rural health centres are dilapidated with absence of drugs and necessary health personnel, rural boreholes and water pumps have no water, rural water scheme/projects are deserted (Tolu, 2014).

Enugu state, is not an exception, the period under review 2007-2015, Musa (2011) asserts that local level has turned into a care-taker imposed by state governments. In some cases, care-takership is perpetuated if the outright denial of democratic local government through care-taker committees demonstrates increase in authoritarian holds on the councils by state governors, the case of where elections hold does not give cause for cheers (Okoli, et al, 2015).That is why in Enugu state, each time a governor assumes office, his first official function will be the dissolution or re-constitution of local government officials whether elected or appointed to secure grassroots support by hook or crook (The nation, 2012 in Okoli, et al, 2015). Many argued that the poor performance of local governments in Nigeria is due to state and local government joint account. Many state governors and state assembly members handle local government as if they are not constitutionally guaranteed democratic elected officials (Mark in Okoli et al, 2015). Again, as a result of joint account, most local government chairmen always complain of shortage of funds released to them, due to the interference of state government in their affairs as orchestrated by governors (FRN in Okoli et al, 2015). Generally, as regards to rural development, the following areas (economic sector, health sector, provision of essential amenities, agricultural sector, general security, industrialization, education sector, transportation and communication sector) have been affected by some of these issues stated above and these areas are the primary assignment of local government but instead of performing as expected, end up doing little.

For instance, it is noteworthy that most of the road networks in rural areas in Enugu state and Nigeria at large are maintained through community efforts. This cannot really be effective as the contemporary road development needs of the rural areas are such that mere community efforts cannot adequately address. There is too, very apparently, poor quality education in most rural areas (Ele, 2006; Ijere ,1992) note in this respect too that rural education is characterized by limited functional or work oriented education and disdain for handicraft and technical subjects. Okoli and Onah (2002:158) make similar observation as they note thus:

The privilege of education which, for instance, is supposed to be a birth right of every Nigerian child is an illusion to many poor rural dwellers. In some places, there are no schools at all while in some others the schools are shabby, ill-equipped and poorly staffed.

Enugu rural areas is equally characterized by apparent lack of health institutions as there are hardly any well-equipped hospital health centres, clinics and maternal homes. Onah and Okoli (2002) observe similarly that in most rural areas in Enugu and Nigeria at large, no medical institution of any sort exists at all and that where they do, the people have to travel 
very long distances to access them.

Water supply in the rural areas has also been discovered to be grossly inadequate and with the spread of water borne disease increased by the accompanying poor sanitary conditions (Ele, 2006; Abah ,2010) observe too that, rural areas in Enugu state is also characterized by depressingly meager annual per capital income, poor liveable houses and various forms of social and political isolation. In summary, there is apparent lack of development in the rural areas in Enugu state as reflected in the near total lack of basic infrastructure, and social services. In Enugu state of Nigeria, for instance, a survey of the development needs of the 471 communities in the state as at 2009 revealed that 385, 342 and 304 rural communities lack access to accessible road, portable water/borehole and cottage hospitals respectively (Enugu state, 2009).

However, good local government administration cannot be underestimated towards rural development in Enugu state. Thus, this paper was embarked upon to establish the nexus between Local Government Administration and Rural Development in Enugu State.

\subsection{Statement of Problem}

Local government is expected to become more meaningful in facilitating rural development at the grassroots level. The merit in involving the local communities' inhabitants as a focal point of good governance in the local government administration is that they serve as a point of contact between the local government and the grassroots (Okafor, 1982 in Zakari ya'u, 2014). Communities in Nigeria in the past have maintained a strong tradition in the area of self-help projects (Okafor 1984 in Zakari ya'u, 2014).

Basic facilities such as roads, bridges, markets, health institutions, primary and post-primary institutions have been provided in different parts of the country through self-help development programmes. According to Okafor 1984, communities have the capacity to respond to specific local development plans, mobilize their resources in a collective way, adjust their organizations to the required needs and devise their own appropriate management rules to cope with the situation (Okafor 1984).

Regrettably, the realization of these objectives has been constrained by a number of issues confronting local government development in Enugu state which are as follows: Joint account system, corruption, state interference, loss of autonomy, caretaker ship, poor commitment and poor funding.

Furthermore, in the key areas according to the four point agenda of Chime's administration, the health centers in most local government is to say the least deplorable. There is abject nonexistence of drugs, medical equipment and manpower.

In the case of essential amenities, basic social amenities as road, electricity, water and recreational facilities are very much lacking in the local government across the state. In the area of agriculture, majority of the rural dwellers depend on this sector but mechanization of the sector remains at a low ebb.

Again, in the area of education, this is an indispensable index of development but much has 
not been done by successive administrations to provide functional qualitative education to the rural dwellers.

Consequently, this research work probe into these principal questions:

1. What role did local government administration played towards rural development in Enugu State, 2007-2015?

2. Did job creation and provision of infrastructures by the government led to decline in rural-urban migration, 2007-2015?

3. To what extent does government's budgetary allocation address rural development in Enugu state, 2007-2015?

\subsection{Objectives of the Study}

In a broad view, this study seeks to look at the local government administration and rural development in Enugu State local government areas. But, being specific, the objective comprises of the following:

1. To assess the role of the local government administration in rural development in Enugu State, 2007-2015.

2. To investigate whether job creation and provision of infrastructures by the government led to decline in rural-urban migration, 2007-2015.

3. To find out the relationship between governments budgetary allocation and rural development in Enugu state, 2007-2015.

\subsection{Scope of the Study}

This research area and dimension of coverage was based on local government administration and rural development in Enugu State. The work is limited to Sullivan I. Chime's administration, 2007-2015. The reason for the time frame is to capture into details fully the relationship between local government and rural development during chime's administration. Again, to the best of my knowledge, research in local government administration and rural development has not been done on the period reviewed (2007-2015). Again, this work centers on Enugu state as a whole and two local governments were selected from each of the three senatorial zones/districts of the state as sample. Under Enugu North senatorial district, Igbo-Eze South and Igbo-Eze North Local Government were covered. In Enugu senatorial districts, Isi-Uzo and Nkanu East Local Government were covered and in Enugu West senatorial district, Ezeagu and Aninri East Local Government were covered.

\section{Literature Review and Research Procedure}

\subsection{Literature Review}

This section is about comments and write up of others about the subject matter. The researcher discussed the literature review in the following headings:

\section{Local Government, its importance/roles and Local Administration}


$>$ Local Government System in Nigeria

$>$ Problem of Local Government in Nigeria

$>$ Local Government and Rural Development

$>$ Funding of Local Government

\subsubsection{Local Government, Its Importance/Roles and Local Administration}

Some form of local government exists in every country of the world. Although there may be differences in the essential features of local government: constitutional status, historical structure, level of autonomy, et cetera, local government is generally seen as veritable agent of development and grassroot participation in a democratic process.

According to Emezi (1984) in Izueke (2010), in a broader definition, sees local government as a system of local administration under local communities that are organized to maintain law and order, provide some limited range of social services and encourage cooperation and participation of the inhabitants towards the improvement of their conditions of living. It provides the community with formal organizational framework which enables them to conduct their affairs effectively for the general good.

Also, in Izueke, 2010, Hill (1974) is of the opinion that if local government is to be effective provider of services, it must be more than efficient, and it runs a risk if it neglects the involvement of the public in a meaningful way, reason being that the local government will still be judged by that justice, fairness, equality and openness by which democratic society as a whole is judged.

However, there is a reasonable degree of divergent ideas among most writers on the meaning of Local Government, although few definitions exist, this is to a large extent a function of the differing socio-economic and political development of local government by most writers.

Some writers defined Local Government as "Local administration set up outside the main focus of the central national or regional administration". The implication of this definition is that there is a glaring absence of legal personality, i.e. ability to sue and be sued, which is the major characteristic of Local Government.

According to the United Nation (UN) office for Public Administration, Local Government is a political subdivision of a nation (or in Federal system or State) which Constitute by law and has substantial control over local affairs including the power to impose tax or exert labour for prescribed purposes, the governing body such as an entity is selected or otherwise locally elected (Zakari ya'u, 2014).

The above definition is akin to the one given by Robson in Zakari ya'u, 2014, who sees Local Government as, "a territorial non sovereign community possessing the legal right and the necessary organization to regulate its own affairs".

Looking at it from the Nigeria context, the guideline for 1976 Local Government reforms suggested a definition of Local Government thus, government at the local level which 
exercised specific powers within defined areas. Viewing the above definitions, Local Government can be seen as the lowest tier of government, established by laws and assigned specific responsibilities.

Also, the above definitions however contained four institutional features of Local Government and they are: First, the Local Government unit must have a legal personality i.e. like the public corporation; it can sue and be sued. Second, it must have specified powers to perform a range of functions. Third, it must enjoy substantial autonomy, especially in financial and staff matters subject to limited control from the central government; and finally, it must have elected representatives along party line or ideological orientation.

In contrast to local government, local government administration has been defined by Rondinelli (1981) as a form of deconcentration in which all subordinate levels of government within a country are agents of the central authority, usually the executive branch, regions, provinces, districts, municipalities and other units of government headed by or are responsible directly to a central government agency and the heads of the local administration serve at the pleasure of the nation's chief executive.

Local administration is therefore, a device established by either the state or federal government for the purpose of administering the localities under its control. It can be established at the federal or central, state or local levels of government.

Furthermore, the Sole Administrator System and the Caretaker Committee of Management established by both General Ibrahim Babangida and General Sani Abacha governments are good examples of local administration. The essential features of local administration are as follows:

(i) It lacks substantive autonomy which makes it impossible for local agents to take any authoritative decisions which are binding on the citizens. It simply complies or acts according to policy guidelines handed down to it by the central authority. The functions of the local body are not provided for in the constitution.

(ii) Local administration exists mainly to execute policies and programmes formulated by the central authority to which it is directly responsible and accountable.

(iii)The central or state government directly appoints and controls the staff of the local administration. Thus, the members of the local body are not elected representatives of local people.

(iv)There exists a defined pattern of hierarchical control of powers and functions and also, of channel of communication from the agents of local administration and vice versa, and which the latter must strictly adhere (Ozor, 2003 in Ezeani,2004).

(v) Local administration lacks financial autonomy. The central or state government determines and controls its finances (Ezeani, 2004).

In his critic of the government of the then Eastern Region of Nigeria, Akpan (1982) in Ezeani, 2004, said by the use of these central government officials in these roles, by limiting the 
financial and executive powers and functions of local governments to the whims and pleasures of the central government; by taking over control of staff serving local governments; by assuming the main financial responsibility for local government services; by taking over control of staff serving local governments, Eastern Nigeria from independence practiced a veiled form of integrated administrative decentralization with the so-called local government serving as nothing but mere arms and agents of the central government.

It is not surprising, therefore, that Ronald Wraith 1982, who has written extensively on local government, once had to change the title of his book from "Local Government in West Africa" to "Local Administration in West Africa" because he realized that in most cases what then existed in West Africa was mere Local Administration rather than local government (Wraith, 1982 in Ezeani, 2004).

Furthermore, in the area of role, According to Egboh \& Attansey, 2009, given its statutory functions and resources, we view the following as the areas in which the local government can facilitate rural development:

a. Economic Sector: The bulk of the population live in the rural areas hence, every economic development measure should take special note of rural dwellers and their problems. Therefore, local governments should be involved in economic planning and execution both of the federal and the state government. That way, they stand a better chance of mobilizing their people to support government policies alleviation measures as well as create jobs for their teeming population. By so doing, they improve their economy and address the problem of poverty.

b. Health Sector: The state of health centers in most local government is to say the least deplorable. There is abject nonexistence of drugs, medical equipment and manpower. Again, there is increasing lack of enthusiasm among health personnel as a result of which most inhabitants of the rural areas resort to traditional medical practices. Some have fallen victims to fake drugs sold by most local dispensaries and medicine shops.

Indeed local government stands a better chance of tackling the health problems of the rural people by addressing the problems bedeviling the sector.

c. Transportation and Communication: Local government should construct and maintain local roads and by so doing ease the burden of transportation hanging on the neck of the inhabitants of rural areas. Also, they can set up mass transit as a way of checking the skyrocketing cost of transportation. In the area of communication, efforts should be geared towards encouraging Global Service Mobile (GSM) services providers to connect the nook and crannies of their localities.

d. Provision of Essential Amenities: Such basic social amenities as road, electricity, water and recreational facilities are very much lacking in the rural communities across the country. Therefore, the local government should partner with the central and state government in providing them. By so doing the problem of rural urban drift will be checked.

e. Agricultural sector: Notwithstanding the craze for oil, agriculture remains the mainstay of the country's economy. Majority of Nigerian depend on agriculture, especially the rural 
dwellers, to generate income. In Nigeria, mechanization of the sector remains at a low ebb. Government can and should come to the help of the farmers by way of providing them with soft loans, subsidized farm inputs such as fertilizer, improved seedlings, insecticides and even farm implements for planting operations. Also, seminars and workshop should be organized during which farmers are taught best agricultural practices.

f. General Security: Security of lives and properties remains indispensable in every developmental planning and programmes. Resources are made and kept or reinvested for greater results or dividends. Hence, therefore, efforts should be geared towards ensuring reasonable peace and mutual co-existence between local communities. Such atmosphere promotes programme and project execution and resources collection.

g. Industrialization: Local government can contribute to rural development through rural industrialization by setting up cottage industries such as garri processing plants, rice milling centers, palm-oil processing units, fishing and livestock outfits etc. Such ventures provide employment to the people and empower them financially. Other ways in which rural development can be attained is by encouraging community projects such as road construction, rural electrification, water projects and so on. Also, local government can address the perennial housing problems facing Nigerians by embarking on housing projects.

h. Education Sector: Education is an indispensable index of development. Though aware of the importance of education in any planned natural development, not much has been done by successive administrations to provide functional qualitative education to Nigerians especially the rural dwellers. Against the backdrop of the important consequences therefore, we expect local government to redouble their efforts in this regards. Not only should schools be built but of important is the need to promote the quality of teaching staff in the schools through training and improved welfare packages. Again, relevant teaching and learning aids such as textbooks, classrooms, office accommodation and furniture should be provided (Egboh, E.A \&Attansey, J; 2009).

i. Encouraging Communal Self-help Projects: In this case, the government at the grass root level should in one way or the other encourage different communities to form an organization or group that will work towards enhancing the rural development in their different villages/communities. This is because; the government cannot tackle the whole problems at a time.

\subsubsection{Local Government System in Nigeria}

Local government is a creation of British colonial rule in Nigeria. It has, over time, experienced change in name, structure and composition (Arowolo, 2010). Between 1930s and 1940s, local government was known as Chief-in-council and chief and council, where traditional rulers were given pride of place in the scheme of things. In the 1950s, election was introduced according to the British model in the Western and Eastern parts of the country with some measure of autonomy in personnel, financial and general administration (Nwabueze, 1982).

It was on this premise that the rising tide of progress, growth and development experienced in 
the local governments in these areas was based. The pace of this development was more noticeable in the South than in the North. During this period, heterogeneity was the hallmark of the local government as there was no uniformity in the system and the level of development was also remarkably different.

The introduction of 1976 reforms by the military administration of General Obasanjo brought about uniformity in the administrative structure of the system; the reforms introduced a multi-purpose single-tier local government system (Ajayi, 2000). The reforms also introduced population criticism under which a local government could be created. Consequently, a population of within 150,000 to 300,000 was considered feasible for a local government (1976 Guidelines). This was done to avoid the creation of non-viable local council and for easy accessibility. There was provision for elective positions, having the Chairman as executive head of local government with supervisory councilors constituting the cabinet. This was complemented by the bureaucrats and professionals, who were charged with the responsibility of implementing policies.

In 1991, a major landmark reform was introduced as the system had legislative arm. In addition, the Babangida administration increased the number of local governments from 301 in 1986 to 453 in 1989 and 589 in 1991. The Abacha regime increased the number to 774 local councils that we presently have in Nigeria (Ajayi, 2000 in Tolu, 2014).

\subsubsection{Problems of Local Government in Nigeria}

A Local Government is an administrative unit with a defined territory, administration authority, power and relative autonomy. It is governed by either selected or elected members from the community. Most countries of the world are apparently committed to establishing Local Governments irrespective of the fact that there is no consensus on whether they should exist or not (Bello-Iman 1996). The problems of Local Governments in Nigeria can only be examined in relation to the objectives upon which its creation in Nigeria was predicated.

The four basic purposes for the establishment of Local Government according to the Local Government Reforms Guidelines (1976) include; enhancement of participatory democracy, promotion of local freedom of action or local autonomy, political integration and national unity, and the provision of services for which they are the most efficient providers compared to other levels of government. It is therefore, obvious from the literature that a number of factors inhibit the actualization of these objectives. The poor performance of Local Government as a tool for promoting rural development and participatory democracy at the grassroots has been constrained by a wide range of factors.

The most notorious of the constraints, according to Bello-Imam (1996) and Enemuo (1999), is inadequate finance. The problem arises from their inability to source for revenue internally couple with insufficient allocation from the central government. This raped them of their functions as they hardly have the finance to execute meaningful rural development projects. Inadequate skilled and experienced personnel are yet another problem. This Ameh (2003) calls Lack of resources, Local Government lack skilled manpower to facilitate a high rate of service delivery. Sorkaa (1999), states that, the era of party politics affects immensely the 
recruitment, discipline and condition of service of Local Government staff and hence the performance of Local Governments in Nigeria.

Another problem is the excessive interference and control by the central government. This undermines local autonomy of the third tier of government. In Nigeria, the federal and state governments have mostly led the dissolution of elected Local Governments chairmen and councilors before the expiration of their tenure. Bello-Imam (1996:208) opines that the intergovernmental relationship between Local Governments and the higher levels of government witnessed suffocating controls and sometimes conflicting directives. This causes a lot of problem to the local level and the performance of Local Governments in general. Corruption, lack of political will and honesty constitutes another serious problem to Local Government performance in Nigeria. Ameh (2003) asserts that, corruption at this level of government covers aspects like embezzlement of finds, falsification of receipts and accounts, inflation of figures on payment vouchers, inflation of prices of goods and services rendered and unnecessary employment of staff.

Sorka agrees with the above when he says that, corruption and unethical behaviour has eaten deep into the fabric of the Local Government system of Nigeria. He further opines that most top functionaries of Local Government are not always objective; administration work is personalized, rules are not taken seriously and sometimes, even discarded completely (Sorkaa, 1992:106:1999;56).

The above implies high incidence of corrupt use of office, lack of integrity and unlawful appropriation of public funds, particularly internally generated revenue for personal gains. This is what the higher level of government used as an excuse for the controlled autonomy of Local Governments.

There is also the problem of inadequate support in some quarters. This stems from the poor performance of Local Government in rural development and service delivery at the grassroots. In the recent past many scholars and even top government officers have called for scrapping of Local Governments in Nigeria. This according to Denga (2003) was as a result of their poor performance of their traditional role in the recent past.

\subsubsection{Local Government and Rural Development}

Local government development is a broad term covering the basic facilities and services needed for rural communities and rural development (FAO, 2006). It is designed as the totality of basic physical facilities upon which all other economic activities in a system depend (African Development Bank, 1999, Geet, 2007). Rural development comprises the assets needed to provide people with access to economic and social facilities and services such as roads, water, drainage, bridges, electricity e.t.c. Local government is a government at the grassroots level of administration meant for meeting the peculiar needs of the rural people (Agagu, 1997). In his analysis, he viewed local government as a level of government which is supposed to have its greatest impact on the people at the rural areas. It is a tier of government which in physical terms is closest to the citizenry and it is saddled with responsibility of guaranteeing the political, social and economic development of its area and its people (Enero, 
Dadoyin and Elumilade, 2004).

Appadorai (1975) observed that there are problems that are local in nature and such problems are better handled by local government because they are better understood by the local people themselves. Based on the 1976 guidelines for local government reform, it is expected that local government should engage in rural infrastructural provision to engender development and good governance at the grassroots. But unfortunately local government still lacks behind in the area of infrastructure, this ugly trend is particularly greater in the area of water and sanitation, rural road access and electricity.

According to World Bank (2004) Nigeria's infrastructure in terms of quality and quantity is grossly inadequate and inferior to that existing in other parts of the world. Out of the 102 countries assessed in the global competitiveness report in 2004, the Nigeria's quality of infrastructure was ranked 3rd to the last, this is consistent with the World Bank survey results where manufacturing firms listed infrastructure as their most severe business constraint. The Nigerian roads were described as the lowest in density in Africa, where only $31 \%$ of the roads are paved as compared to $50 \%$ in the middle income countries, and even where roads are provided, only $40 \%$ of these roads can be said to be in good condition (Alabi and Ocholi, 2010). Currently only $20 \%$ of Nigeria's rural population have access to electricity.

In Nigeria, it was observed in Amuro district in Kogi State that passengers pay 3 times for kilometer on untarred rural roads compared to tarred roads. A nation-wide survey was conducted by the Central Bank of Nigeria $(\mathrm{CBN})$ on the state of roads in the country, the survey revealed that the road network, as at December 2002, was estimated at 194,000 kilometers, with the Federal Government being responsible for $17 \%$, state government $16 \%$ and local government $67 \%$. It was also shown that most of the roads were in bad condition, especially those in rural areas (CBN, 2002). Some of the roads constructed over 30 years ago had not been rehabilitated even once, resulting in major cracks and numerous potholes that make road unsafe. Water is critical to human existence but yet a serious problem of human survivals, health and economic development. Millions of people in developing countries are faced with acute water stress from inadequate supplies.

Survey conducted by Hall (2006) revealed insufficient or lack of provision of pipe borne or portable drinking water where $50 \%$ of the city dwellers and $90 \%$ of rural dwellers lack access, as a result, large proportion of households have resorted to drawing water from unhygienic sources. Most of the rural areas in Nigeria are in a pathetic state of infrastructure delivery, even, some of the urban local government areas are also deficient in infrastructure delivery. Some of these infrastructures where available, are left uncared for.

The implication of this is that local governments in Nigeria have been consistent over the years in their failure to enhance their capacity to engage and mobilize the people and to respond to their needs and to administer effectively and responsibly the various local services needed for grassroots development. Local roads are left unrepaired, rural electricity are in state of dilemma, rural health centres are dilapidated with absence of drugs and necessary health personnel, rural boreholes and water pumps have no water, rural water scheme/projects are deserted. The only visible things in the rural areas are the sign post that shows the 
location, direction, and physical status of these rural infrastructures. So many of them are not functioning due to long years of existence, lack of maintenance, uncompleted nature of the projects, vandalization, lack of quality job and absence of community ownership of such projects (Tolu, 2014).

\subsubsection{Funding of Local Government}

Resources in local government can be seen in terms of human, material, and financial. However, the crucial resource is financial resources, because it gives meaning to the mobilization of human and material resources, which indeed promotes development at the grass-root (Zakari ya’u, 2014).

Danjuma (1994) as quoted by Solomon (2004) posits that, revenue allocation refers to the mechanism for sharing the country's financial resources among different tiers of government in the federation, with the overall objective of enhancing economic growth and development, minimizing inter-governmental tensions and promoting material unity (Zakari ya'u, 2014).

The Federal Constitution of 1999 has shown that statutory allocation is however a joint responsibility between the state and the federal governments as depicted in the fourth schedule section 6(a) that the national assembly shall make provisions for statutory allocation of public revenue to local government council in the federation, and (b) that the house of assembly of state shall make provisions for statutory allocation of public revenue to local government councils within the state (Zakari ya'u, 2014).

Local government as the third tier of government requires adequate funds in order to discharge their assigned duties effectively. The sources of revenue for local government are numerous. According to Ezeani, 2004, there are two traditional sources of local government revenue in every country of the world: external and internal. The external sources include statutory allocation, grant in-aid by the government and loans. The internal sources comprise taxes, rates, licences, fees and fines; earning from commercial undertakings, interest on investment, et cetera.

\subsection{Hypotheses}

This study is guided by the following hypotheses:

1. Local government administration played significant role in rural development in Enugu state 2007-2015.

2. Job creation by the government led to decline in rural-urban migration, 2007-2015.

3. Government budgetary allocation significantly addresses rural development in Enugu state 2007-2015.

\subsection{Research Procedure}

\subsubsection{Research Design}

A research design is a plan that guides the investigator in the process of collecting, analyzing and interpreting observation. It is a logical model of proof that allows the researcher to draw 
inference concerning causal relations among the variables under investigation (Bailey,1994).

Giving the descriptive and argumentative nature of the paper, qualitative method of data gathering and analysis were adopted in the conduct of the research. In other words, the materials considered for the research were obtained from books, journal articles, internet sources, official publications, among others.

\subsubsection{Sources and Method of Data Collection}

For the purpose of generating data for this study, we made use of documentary sources which is also known as secondary sources from related literature on Local Government Administration and Rural Development in Enugu state 2007-2015.

\subsubsection{Method of Data Presentation and Analysis}

The method of data presentation and analysis adopted for this study is the content analytical method. Thus, under the findings and discussion section, each discourse was based on some background assumptions presented in the form of hypotheses. These hypotheses are subsequently, either validated and upheld or rejected or ignored. Furthermore, Presentation and analysis of data was therefore based on deductions from the issues raised in the study in the light of available data gathered.

\section{Discussions and Findings}

This section is based on the analysis of the hypotheses. This provides the needed understanding and direction to the work.

\subsection{Discussions}

The discussions of this study are as follows:

1. Local government administration played significant role in rural development in Enugu state 2007-2015.

2. Job creation and provision of infrastructures by the government led to decline in rural-urban migration, 2007-2015.

3. Government budgetary allocation significantly addresses rural development in Enugu state 2007-2015.

Hypothesis One: Local governments played significant role in rural development in Enugu state 2007-2015

Poor state of essential amenities has projected a bizzare image of Nigeria as a country with capital flight, capital sink and capital stagnancy. But since 1999, at the onset of our democratic experiment, the country has made efforts to lay a foundation for economic growth and development. Nigeria is Africa's largest economy and a major player in the global economy.

But her huge infrastructure deficit has constrained economic growth and development, thus inhibiting her ability to improve the quality of life as envisaged by her governments at several levels. Nigeria's infrastructure is in a deplorable state and the nation's infrastructural needs are 
evident for all to see.

The road system is the most important element in the country's transportation network, carrying about 95 percent of all the nation's goods and passengers. But currently, many of the roads are in disrepair because of poor maintenance and years of heavy traffic (Chioma, 2014). In recognition of this fact, local governments worked with the state government and initiated a programme called Visit-Every-Community (VEC) initiative that will facilitate infrastructural development at the local governments. This particular programme helped in legacy projects and serve as a roadmap in line with the choices and aspirations of the people as outlined in the Four- point Agenda (Infrastructure, Health, Education and Agriculture) of the government and it will give priority attention to constructing new roads and rehabilitating numerous others in various states of disrepair. The reason was simple; it was meant to improve travel times, enhance connectivity with our rural communities and reduce road accidents and other vices associated with bad roads. Getting this done created way for other amenities to be established in the local government (Uzodinma, 2013).

In the area of health, the Free Maternal Child Healthcare came up. The FMCH programme was launched and the primary reason was to reduce infant and maternal mortality in the state. It has been so effective that government purchased the Colliery Hospital in Enugu which it intends to upgrade and dedicate exclusively as a mother and child Hospital. In addition, several health facilities have been built and /or renovated. The Enugu State Medical Emergency Response Team (ESMERT) has been a success story as it has saved many lives and greatly helped people involved in trauma and other life-threatening emergencies (Uzodinma, 2013).

Again, Enugu state under the period reviewed engaged the services of Partnership for Transforming Health Systems (PATHS). The PATHS was originally a six-year (2008-2014) development initiative aiming to ensure that Nigeria achieves important health-related Millennium Development Goals. Implementation of the programme was extended by Department for International Development (DFID) to January 2015 in Jigawa, Kaduna and Kano; and July 2016 in Enugu and Lagos. PATHS is funded by United Kingdom (UK) aid from the Department for International Development, PATH is working in partnership with the Government of Nigeria and other stakeholders to improve the planning, financing and delivery of sustainable health services for those most in need. In addition to its work at the federal level, implementation continues in Enugu and Lagos States, facilitating Public Private Partnerships (paths2.org).

The vision of PATH is a transformed Nigerian health care system providing sustainable, accessible and responsive health care services and as a result of that, they were able to perform in the following areas; Community outreach boosts attendance in Enugu Health Centre, Supervising health workers to improve quality of care, Delivering essential health supplies to Enugu health facilities, Doctors volunteer to work in rural health facilities in Enugu State, Equipped with new skills to save lives of women and newborns, Igbo-Etiti channels resources strategically to address health needs, Improving services efficiency in poly district hospital, PATHS empowers Isigwe Community in Enugu State to build health 
centre, Revamped health centre brings services closer to home, Volunteer doctors tackle health needs of rural communities, workload assessment paves way for new health workers in Enugu State (paths2.org).Nevertheless, during the reporting period the State also recorded some remarkable achievements in this health sector especially in terms of development of Policy Documents such as State Strategic Health Plan, Human Resources for Health (HRH) Policy Public Private Partnership (PPP) in Health Policy, National Health Insurance Scheme (NHIS) law and Medium Term Sector Strategy. These policy initiatives helped the Ministry of Health in ensuring sector coordination and leveraging on partnership with our development partners and Local Governments, to address some health challenges during the period under review. Equally, the Sector also rehabilitated many health facilities, provided drugs and services as well as conducted assessments of the Enugu Health Sector Performance and Human Resource for Health in Enugu State which were used to ascertain the performance in Health Sector in the State (Enugu State Vision4:2020).

In the area of education, education is an agent of national development. Its importance cannot be overemphasized. Education is believed to enhance the quality of living of individuals and to some extent narrow the gap between social classes.

In line with the above statement, the state and its local government found it worthy to initiate a programme called The Free Basic Education Policy: This programme covered children in primary and post-primary schools up to Junior Secondary School (Jss111) which was a success story towards preventing children from dropping out of school and getting them right at the formative stage of their lives (Uzodinma, 2013).

Again, Ugo and Ukpere, 2009 asserts that the invaluable role of the local government with the attendant development measure to the people has become a relevant discourse of our time. It integrates the people into plans and polices of government. Local government has historically provided services of importance to its citizens in rural and urban areas which include provision of basic services like water, roads, health facilities e.t.c (Odoh, 2015).

In areas of agriculture and employment, Enugu State Government considering the importance of agriculture made enormous investment in this sector during the period under review. In order to enhance and improve food production, the State Government established Songhai Enugu Initiative, an integrated Commercial Agricultural Programme that is targeted towards achieving net self-sufficiency in food production by 2015 in the State. Notwithstanding the resource challenges, the Sector made some achievements in this regard which include identification and redesigning of 11 no agricultural facilities in the State, establishment of rootstock nursery and bud wood garden, demonstration and commercialization of citrus project, distribution of 50,000 bags of organic fertilizers and 60,000 bags of inorganic fertilizers as well as clearing of 400ha of land for Oil palm plantation at Ugwu and Umulokpa within the reporting period. Additionally, the State also recorded substantial achievements in the Enugu Songhai Initiative programme which include procurement of 25 no tractors for agriculture commercialization, training of over 172 Youth graduates (consisting of equal numbers of males and females) at Songhai Regional Centre, Republic of Benin on various Agricultural practices, development of master plan for Adarice Green City as well as building 
of animal pens, land clearing and drainages, sitting of boreholes, Block Production, Reception Hut, Agro-forestry/orchard at the green city within the period under review. In terms of output, a total number of 473 hectares of land were cultivated in 2011 which produced an aggregate number of 2,026 metric tones of varieties of crops such as Rice, Cassava, Maize, Pumpkin, Nsukka Yellow Pepper, Garden Egg Plant, Carrots, Tomatoes, Lettuce and Cabbage. Also over 50 cooperatives and individual farmers are also engaged as satellite farmers. Currently complete processing units are being installed with all infrastructure, machinery and milling facility (rice processing equipment for capacity of app. $30,000 \mathrm{MTN}$ ser year for all the rice production from the internal farms and also from external farms). In Heneke, site clearing, construction of access roads, 2no artesian wells and 2no fish ponds including development of 2,000 improved palm trees and 480 bananas have been completed within the reporting period. Apparently to support the State's Vision goal in Agriculture, one of the World Bank supported projects in the State like Commercial Agricultural Project also intervened to strengthen agricultural production systems and facilitate access to market for targeted value chains (Poultry, Fruit trees and Maize) among 10,000 small and medium scale commercial farmers in Enugu State, with about $70 \%$ being rural women. During the reporting period, a total of 6 Community Interest Group (CIGs) consisting of 71 male and female commercial farmers benefitted from the World Bank support which increased their pineapple Value Chain production from 35 metric tons in 2009 - 162.7 metric tons in 2011 showing $26.5 \%$ increase. In maize Value Chain production, 38 CIGs consisting of 393 commercial farmers benefitted from the World Bank support which increased the production from 220 metric tons - 330 metric tons representing $69.7 \%$ increase while in Poultry Value Chain Production (Broiler), 11 CIGs consisting of 123 commercial farmers benefitted from the World Bank support which increased the production from 703,500birds in 2009 - 936,000 birds in 2011 representing 45.6\% increase. Equally in Poultry Value Chain Production (Layers), 11 CIGs consisting of 128 commercial farmers benefitted from the World Bank support and their production increased from 71,400 crates in 2009 - 489,905 crates in 2011 representing 69.2\% increase. Holistically, about 715 commercial famers benefited from the programme during the reporting period which will also have multiplier effect on the economy of the State (Enugu State Vision4:2020).

From the foregoing, it can be deduced that local governments and the state at large played significant role towards rural development in Enugu state. Therefore, the hypothesis is upheld.

Hypothesis Two: Job creation and provision of infrastructures by the government led to decline in rural-urban migration, 2007-2015

The mild climate and vast opportunities of Enugu, in southeastern Nigeria, have drawn people and investment. Confronted with chronic energy shortages that drive residential and commercial reliance on petroleum-based generators, the city worked to manage population flows and establish cleaner, more reliable energy. Unreliable power has driven manufacturing away from the state, and new building developments have remained energy intensive, putting greater strain on the system and the environment (Tlfirst, 2017). 
Under the period reviewed, the state has created an investor haven, with good private sector participation policies, a good development plan and framework, improved infrastructure, public security and tax regime for investors. The outcome of the efforts of the State in this direction recorded massive inflow of both local and international investors who invested in some areas such as recreation centres, hotels, eateries, cinema, shopping malls, industry, commercial agriculture etc. These investments have not only created jobs for the inhabitants (rural and urban) of Enugu State but also alleviated poverty and reduced crime rate in the State. The Polo Park Shopping Mall where SHOPRITE, GAME, MAX, HUB and other sophisticated shops are situated as well as INNOSON group of Industries are typical examples of huge investment made by Private Investors in the State during the reporting period. The big investment created multiplier effect as many other businessmen and women became engaged in sale of varieties of goods and services and on the other hand creating not less than 5000 job opportunities for our teeming population (Enugu State Vision4:2020).

Again, as part of the State efforts to improve the enabling environment for investors and tackle the challenge of unemployment, the State Government through strong Private Public Partnership procured and distributed 500 Coal City Cabs and 50 Coal City buses to transport operators in rural and urban areas. In order to facilitate repayment process and encourage the operators' commitment to expanding the business, the State Government chose to write off the interest element as additional incentive. This shows that 100 percent of buses and taxis targeted in the Plan have been achieved within the period under review and significantly, the scheme has also provided about 800 persons with job opportunities and improved the transportation network in the State (Enugu State Vision4:2020).

Furthermore, in order to enhance service delivery in the Local Government system and the Primary Health Care in the State, the SPOT CHECKS was initiated to monitor attendance of Local Government Staffs and recruitment of 32 doctors, 259 nurses, 25 pharmacy technicians, 18 Medical Lab assistants and 1156 Community Health Extension Workers to address the manpower shortages at the Primary Health Care facilities in the State. Additionally, 17 planning officer were converted and posted to the 17 Local Government Councils to ensure adequate planning and budgeting in the LGCs for sustainable development (Enugu State Vision4:2020).

In area of infrastructure, the Enugu state government created Nigeria's first city-specific development agency to manage its development, the Enugu Capital Territory Development Authority (ECTDA). ECTDA works to administer the city's assets and plan for its future. It manages city infrastructure and urban development planning and coordinates between state level government department tasked with governing Enugu's power supply, roads and services; all fundamental facets of resilience. However, building a new agency from scratch is no easy task, so, the Nigerian Infrastructure Advisory Facility (NAIF) worked alongside ECTDA offering technical assistance to support more effective city development planning and service delivery. Funded by the Department for International Development (DFID) and implemented by Adam Smith International, Nigerian Infrastructure Advisory Facility (NAIF) works in partnership with the state governments to build capacity for resilient rural and urban development (Tlfirst, 2017). 
The government's rural development programs emphasize road construction and rehabilitation aimed at improving access to the hitherto marginally exploited farmlands and evacuation of agricultural produce to the urban centers. Rural electrification is also pursued vigorously as a necessary infrastructure for the success of small scale industrial schemes. Various agricultural innovations are were introduced and the farmer everywhere was encouraged to go into large scale farming through adoption of these innovations which include tractor tilling of the land, irrigation practices, land consolidation and intensive farming, seed and livestock breeding and multiplication, fish farming, etc. Source improvement to provide clean and safe potable water in the villages, provision of Primary Health Care (PHC) facilities, and development of effective rural information delivery systems are other important dimensions of the rural development program (Tlfirst, 2017).

The activities of the People's Bank of Nigeria in the state have encouraged many communities to establish Community Banks, and through them a lot of rural people, groups and organizations have received credit facilities for broad based enterprises.

Effective community governments, through community development associations or town unions, are also being put in place to promote rural development. With all these rural development programs there has been an increase and diversification of skilled manpower, reduction of unemployment, institutionalization of self-reliant culture, availability of social amenities as well as reduction of incidence or rural urban migration (Tlfirst, 2017).

From the foregoing, it can be deduced that Job creation and provision of infrastructures by the government led to decline in rural-urban migration in Enugu state (2007-2015). Therefore, the hypothesis is upheld.

Hypothesis Three: Government budgetary allocation significantly addresses rural development in Enugu state 2007-2015

The Reviewed period showed Plan projected a total resource envelope of $\$ 427,308,369,000$. Out of this, the total projected revenue from Federation Allocation (FAAC) is $\$ 278,752,959,000$ representing $65.2 \%$; Internally Generated Revenue (IGR) is $\$ 45,737,970,000$ representing $10 . \%$; Value Added Tax (VAT) is $¥ 53,025,309,000$ representing 12.4\%; while other Capital Receipts amount to $\$ 49,792,131,000$ representing 11.7\% of the total resource envelope(ENV4:2020). The projected expenditure profile for both the State and 17 Local Government Councils of Enugu State amounts to $\$ 427,308,369,000$. Out of this amount, the projected recurrent expenditure for both State and 17 LGCsamounts to $\$ 247,589,951,000$ representing $58 \%$ while total capital expenditure accountsfor $\$ 179,718,418,000$ which represents $42 \%$ of the projected total investment size for both the State and 17 LGCs of Enugu State (ENV4:2020). In line with the main thrust of His Excellency, the Governor of Enugu State S. I. Chime in his second tenure, the infrastructural sector received the highest allocation for the plan period which is 43,878,104,000 (35\%) of total capital budget followed by Education sector with $\$ 20,174,941,000$ (16\%); Health $\$ 15,117,730,000$ (12\%); Information, Culture and Tourism $\$ 9,539,000,000$ (8\%), while Good Governance and Security is $\$ 9,049,167,000$ of the proposed capital size within the reviewed period. The allocations will enable the State implement the proposed programmes 
and projects as highlighted in the Plan document (ENV4:2020).

From the foregoing, it can be deduced that Government budgetary allocation significantly relate to rural and urban development in Enugu state. Therefore, the hypothesis is upheld.

\subsubsection{Findings}

Based on the data collected the following findings were made: local governments in Enugu State were able to achieve developmental projects in their respective jurisdictions towards improving the standard of living. For instance, in Igbo-Eze South local government under the Enugu North senatorial district, the local government worked aggressively and assiduously towards rural development like construction of Ovoko-Iheakpu road, Iheakpu-Awka/Ibagwa road, Alor-agu/Uradu/Itehi road, Nkwo Ibagwa road, Orie Iheaka road, Ovoko-orba road and Itechi-Ibagwa road. In area of support for education, the local government constructed classroom block at Alor-agu, Abulegu. In area of health, there was construction of Isiagu health centre and other projects which include the electrification of Ohagu Ovoko, re-roofing of council's secretariat, equipping of the Neighbourhood watch group, reconstruction of burnt Udeze development centre's office block and furnishing of Doctor's and Pharmacist's quarters. All these projects above were based on the needs of the local government during the reviewed period.

In Igbo-Eze North local government under Enugu North senatorial district, the local government worked towards improving the standard of living by embarking on pressing needs developmental projects for the people. These projects are: construction of Ogrute-Ufuogbo-Isiugwu-Umuopu-Ofantekogi road, Ogrute-Nkpamute-Igogoro-Ikpamodo-Okpo-Amaja road and other projects include electrification projects at Olido and Umuonu, Sinking of boreholes at ette centre, Aji, Agbon'omuolaga, Provision of vehicles with security gadgets and construction of health centre at Umuishi. All these happened in conjunction with the state initiatives like VEC, FMCH and so on.

Again, in Isi-Uzo local government under Enugu East senatorial district, the government worked aggressively and assiduously towards improving the rural development. For easy access to different towns, the government constructed roads such as the construction of Nkwo Neke-Amanyi River road, Ekeaha-Amufu Roundabout-Mgbuji road, Ijogwu Bridge. Support for education, the government constructed six classroom block in Neke, four classroom block at Ikem Nkwo, construction of ICT centre, Neke and lock up shops. In area of electrification, the local government provided and installed four units of 300KVA transformers at Agudene Mbu, Emerora Neke, Mkpunator Ikem and Ape Mgbuji respectively, and installation of $500 \mathrm{KVA}$ transformer at the local government headquarters.

In Nkanu East local government under Enugu East senatorial district, in improving the level of living the local government worked hard in area of road constructions and those roads are Idodo-Oruku road, Owo-Ubahu- Amankanu road, Nome-Mburubu-Nkerefi road, Amafor Ugbawka road, Ihuokpara road, Umuawalagu-Isiogbo road, Ezza-Akuoga-Oruku road, construction of four culverts in Ezza-Akpuoga-Oruku link road, two culverts in Ihuokpara 
road, eight ring culverts in Owachi Ubahu, construction of $17 \mathrm{~km}$ road in Nara-Mburubu-Nome-Nenwe road, 5-6km road in Ugwuomu-Odobudo-Owachi-Ubahu link road, $5 \mathrm{~km}$ road in Ihuokpara-Akpugo road, 3km Nkwo Ihuokpara-Obodo Nwatu road, construction of Atava-Ndiagu-Ishienu Amagunze road, construction of Amaofia-Ogo-Owor road. Still in Nkanu East, many renovations were done in areas of health and schools. For instance, there was renovation of Oruku community school, Mbufubu primary school, construction of Oruku Health Center and Ugbawka health center.

In Enugu West senatorial district, Ezeagu local government was examined on impact made towards rural development. From our assessment, Ezeagu embarked on developmental projects for the good of the people and these projects are: the construction of new classroom blocks at Girls Secondary School, Aguoba-Owa, four units squatting toilet at Girls Secondary School, Aguobu-Owa, new classroom blocks at Umualor, renovation of classroom blocks at Boys Secondary School, Aguoba-Owa, Installations of 500KVA transformers at Afor-Ugwu and Obodongwu respectively and construction of Eke Ozom-Mgbagbu Owa road.

Aniri local government was examined also towards the impact made in improving the standard of living. Aniri is a local government under Enugu West senatorial districts. The local government worked on the following developmental projects like construction of electricity projects at Oduma, Ogbaku, construction of development centre secretariat in $\mathrm{Mpu}$, Ihuogiri-Nenwe/Oduma road, Amachalla Onovo-Nzerem road, Amaegwu Amunkpa-Ogbombara-Etitiama-Onuihialla road, Amachalla Onovo-Nzerem road, in supporting education, the government at the grassroot level constructed five classrooms building at Community Primary School, Obeagu Oduma, five classroom building at Community Primary School, Amaeze Okpanku, five classroom building at St Theresa Primary School, Uhuogiri road which connects Nenwe and Oduma village.

Finally, from the above we can say those were the projects executed during the reviewed period. Again it was discovered that government budgetary allocations actually affected the overall development of the rural communities. The study reveals that there is no adequate budgetary allocation for rural development given government limited resources. This accounts for why the government came out with the policy of co-funding projects with communities and donor agencies and as a result of that, Enugu state government was able to execute good number of projects in many communities between $2007-2015$.

\section{Summary, Recommendations and Conclusion}

\subsection{Summary}

This study dealt with Local Government Administration and Rural Development in Enugu State (2007-2015). The work is guided by three research questions which are as follows; what role did local government administration played towards rural development in Enugu State, 2007-2015? Did job creation and provision of infrastructures by the government led to decline in rural-urban migration, 2007-2015? To what extent does government's budgetary allocation address rural development in Enugu state, 2007-2015?

The work also has three specific objectives; To assess the role of the local government 
administration in rural development in Enugu State, 2007-2015.To investigate whether job creation and provision of infrastructures by the government led to decline in rural-urban migration, 2007-2015. To find out the relationship between governments budgetary allocation and rural development in Enugu state, 2007-2015.

Furthermore, three hypotheses guided this work: Local government administration played significant role in rural development in Enugu state 2007-2015. Job creation and provision of infrastructures by the government led to decline in rural-urban migration, 2007-2015. And, Government budgetary allocation significantly addresses rural development in Enugu state 2007-2015.

\subsection{Recommendations}

Based on the findings, the following recommendations have been made:

1. The roles played by the local governments can be said to be very successful. Though, there is need for the government to increase their function capacity of these projects and programmes to be able to cover every area of the state.

2. We recommend that the government should always maintain a balance in development both in urban and rural areas of the state to minimize migration.

3. The local government as grassroot government is increasingly challenging. Because of this, there is need for the federal allocation to be increased and has to go straight to the local government account to avoid interference by the state government and caretakership system should be stopped, by so doing, it will go a long way in having more developmental projects.

4. Local government needs to diversify their internal revenue sources by engaging in some business ventures like filling stations, transportation, and so on, to be able to compliment the poor budgetary allocation given to them by the federal and state government.

\subsection{Conclusion}

The research looked at local government administration and rural development in Enugu State within the period 2007-2015. The study revealed that within the period under review, there was a significant improvement in the provision of basic infrastructure and general poverty in various communities in the state. The general observation made in the state showed that provision of basic infrastructures and other development projects skewed more to the urban areas to the detriment of the rural areas were majority of the population live.

\section{References}

Abah, N. (2010). Development administration: A multi-dispensary approach. Enugu: John Jacob Classic Publishers.

Adeyemo, D. (2005). Local government in Nigeria: A historical perspective. [Online] Retrieved from http//www.elgf.org.uk/index.cfm/pageid/112/Nigeria. https://doi.org/10.1080/09718923.2005.11892462

African Development Bank. (1999). Infrastructure development in Africa: African 
development report 1999. Oxford: Oxford University Press.

Agagu, A. (1997). Local government. In Kolawe .D. (Ed) Readings in Political Science, Ibadan:Dekaal Publisher.

Agagu, A. (2004). Continuity and change in local government administration and the politics of underdevelopment. In Agagu .A. and Ola, R. (Eds) Development agenda of the Nigerian State. Ibadan: Fiag Publisher.

Aghayere, V. O. (1997). Dominant issues in the Nigerian local government system: A contemporary focus. Lagos: Imprint Services.

Ajayi, K. (2000). Theory and practice of local government. Edo Ekiti: UNAD Aknul (2004).

Ameh, I. O. (2003). Unique problem of local government. In Denga D. (Ed) Local government administration in Nigeria: Past present and futuristic projects. Calabar: Rapid EducationPublishers.

Anifowose. R., \& Enemuo, F. (1999). Elements of politics. Lagos: Malthouse Press Ltd.

Appadorai, A. (1975). The substance of politics. New Dehil: Oxford University Press.

Arowolo, D. (2010). Local government administration and the challenges of rural development in Nigeria. In Agagu A., Afinotan .L., Arowolo .D., and Lawal .T. (Eds) Public administration in Nigeria. Akure: Alabi-Eyo\& Co. Ltd.

Bailey, K. (1994). Methods of social research. $\left(4^{\text {th }}\right.$ ed.). New York: The free press.

Bello, I. B. I. (1996). Local government in Nigeria: Evolving a third tier of government. Ibadan:Heinmmann, the Educational Books.

Bolaji, et al (2011). Local government budget watch. Lagos: Human Development Initiative.

Central Bank of Nigeria (2002). Highway maintenance in Nigeria: Lessons from other countries.Abuja: CBN.

Chioma, G. (2014, August 24). Poor infrastructure: The sad story of a nation. The Vanguard Newspaper. [Online] Retrieved from https://www.vanguardngr.com/2014/08/poor-infrastructure-sad-story-nation

Constitution of the Federal Republic of Nigeria 1979. Lagos: Federal Government Printer, Section, 7(1).

Denga, D. J. (2003). (ed) Local government administration in Nigeria past, present andfuturistic projects. Calabar: Rapid Education Publishers Encyclopedia of social science (1972:459).

Ele, C. (2006). Evangelization through rural development. Nsukka: Great AP Publishers Limited.

Enero, J., Oladoyin, A., \& Elumilade. (2004). Accountancy and transparency in revenue. generation: the case of local government in Nigeria. International Review of Politics and 
Development, 2(2), 1-3.

Enugu State Vision 4:2020 (n.d) Revised ENV4:2020 Medium Term Implementation Plan 2012-2015 [Pdf].

Enugu State. (2009). Medium term implementation plan-Enugu State Vision 2020 (2010-2013). Enugu State Government Publication.

Ezeani, O. E. (2004). Local government administration. Zik-Chuks Printing Press: Enugu.

Food and Agricultural Organization (2006). Technical consultation on rural infrastructure issues and rural infrastructure and challenges. [Online] Retrieved from www.fao.org/ag/magazine/ags-infra.pdf. Access Date: 20/06/2017.

Geet (2007). Infrastructure challenges to South Asia. [Online] Retrieved from http://www.adbi.org/discussionpaper2007/09/27/2364.infrastrucvture.challenges.south.asia Access Date: 25/07/2017.

Hall, D. (2006). Water and Electricity in Nigeria: A report commissioned by public service interaction unit (PISRU). Business School of University of Greenwich, London. [Online] Retrieved from www.world-post.org. Access Date: 25/07/2017

Ijere, M. (1992). Leading issues in rural development Enugu: Acena Ventures.

Izueke, E. M. (2010). Local government administration and good governance in Nigeria. Nigerian Journal of Public Administration and Local Government, 15(2), 74-90, ISSN: 0189-8094

Musa, A. (2011). The challenges for improving local government system in Nigeria. The 3rd biennial conference of community development in Nigeria. Asaba, November 20-24.

Mustard, F. J. (2010). Early brain development and human development. Encyclopedia on early childhood development.

Nakpodia, E. D., \& Achugbue, M. D. (2012). Problems encountered in the management of nursery and primary schools in Delta State, Nigeria. Journal of Public Administration and Policy Research, 4(6), 140-148. https://doi.org/10.5897/JPAPR12.003

Newcombs, T. (1953). The Inter-dependence of socio-psychological theory and method: A brief overview on research methods in the behavioural sciences. New York; HIT, Rinehart and Winston.

Nwabueze, B. (1982). A constitutional history of Nigeria. London: Longman.

Nwangwu, I. O. (2003). Educational policies in Nigeria: Trends and implication. Nsukka: Jobus International Press.

Odoh, F. A. (2015). An examination of rural development in Enugu State 2007-2013.

Okoli, F. C, Nnamani, D. O., \& Eberinwa, O. M. (2015). Local government and good governance in Enugu State, Nigeria (2000-2012). Review of Public Administration and 
Management, 4(8), 156-171.

Okoli, F., \& Onah, F. (2002). Public administration in Nigeria: Nature, principles andapplication. Enugu: John Jacobs Publishers limited.

Oviasuyi, P. O., Idada, W., \& Lawrence, I. (2010). Constraints of local government administration. Nigeria Journal of Social Science, 24(2), 81-86.

PATHS2 (n.d). Case study bulletins. [Online] Retrieved from http://paths2.org/resource-center/case-study-bulletins. Accessed Date: 30-6-2018.

Rondinelli, D. (1981). Government decentralization in comparative perspective: theory and practice in developing countries. International Review of Administrative Sciences, XLVII(2), 137. https://doi.org/10.1177/002085238004700205

Salawu, R. O. (2005). Essentials of public finance. Ile-ife: Obafemi Awolowo University.

Sorkaa, A. P. (1999). Local government as third tier of government in Nigeria: A critical assessment. Nigeria Journal of Public Administration and Local Government, 2.

Tlfirst. (2017). Urban concerns in Enugu. [Online] Retrieved from www.Tlfirst.com. Accessed date 30-6-2018.

Tolu, L. (2014). Local government and rural infrastructural delivery in Nigeria. International Journal of Academic Research in Business and Social Sciences, 4(4), 139-147.

Uzodinma, E. (2013). Full text of the 2014 budget estimate presented by Governor Sullivan Chime of Enugu State. [Online] Retrieved from: https:// www.google.com.ng/amp/dailypost.ng/2013/12/10/full-text-2014-budget-estimate-presentedgovernor-sullivan-chime-Enugu-State. Access Date: 14/10/2017.

World Bank (2004). Rural infrastructure in Nigeria: Addressing gaps in service delivery. [Online] Retrieved from http://www.worldbank.org.am/website/external/ counteries/ ecaext/nigeria. Access Date: 10/05/2017.

ZakariYa'u, I. (2014). Assessment of the impact of local government on rural development in Soba and Zaria local government areas Kaduna State (2006-2011) '. Retrieved on 10th June, 2017, Online [PDF].

\section{Copyright Disclaimer}

Copyright for this article is retained by the author(s), with first publication rights granted to the journal.

This is an open-access article distributed under the terms and conditions of the Creative Commons Attribution license (http://creativecommons.org/licenses/by/4.0/). 